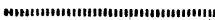

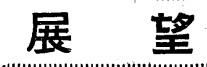

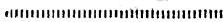

\section{メトロポリタン・エリアに関する 若干の問題}

小林博

metropolitan area, 或は metropolitan region は, 我国では大都市圈, 大都市広域 圈，大都市地域，大都市区域，メトロポール地域などといわれ，又時に原語のまま使 用されている。

これらは今世紀に利りる metropolitanization を空間的他地域現象として把握した

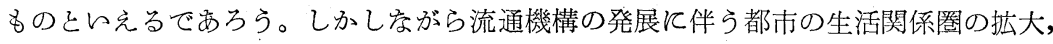
交通通信機関の進歩を媒介とする人口・諸機能の, 大都市集中, その周辺への分散, それ飞基づレて urban 岁ものが都市だけに止らず rural 宗地域の中飞渗透して行く ことなどの結果离らわれたとの現象は, もともと人間生態学乃至は都市社会学の分野

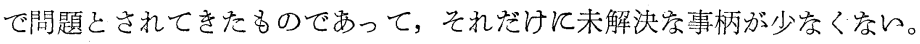

筆者汢これらを網羅的に展望するだけの力をもた少いのでとの若干についてふれて みたい。

metropolitan region 或は area（以下単にリージョン又はェリアと略称する）の研 究仗，1930年前後と1950年前後頃に二つの昂揚期を以るととができる。

前者方自動車の普及によって著し々郊外の発達をみ, metropolitan community 的 性格が米国の大都市を中心現実化したとと背景としているようである。そして研 笁の理論的根拠としては R. E. Park や R. D. Mckenzie そよる人間生態学の提唱 が亦づかって力が亦った。中でも Mckenzie はこの研究のパイオニアとレわれる。

しかし metropolitan という語はとれより早く R. B. Grassとょって用いられた。 彼は1922年 An Introduction to Economic History (1922) 飞柇て, 新しい技術に 適応して新しい地域構造が形成される点飞注目し西洋交化の発展を五つにわけ，現代 を metropolitan economy の時代とした。とれは生産者と消費者が互に物資とサービ スに依存している組織で严り，その中で彼等の需要が中心都市に集中している交換の 
384

組織によって供給されるしくみであるとし metropolis の重要性を指摘した。

しかし彼は metropolis とその後背地は互に相互依存の関係にあり一つのユニット をなすとしてらる(Bogue, D. J.: The Structure of the Metropolitan Community p. 8.1950)。Mckenzie 怯地域社会の生態学的研究から，自動車交通の進歩を媒介とし て大都市が周辺の小都市やその他の地域に支配的学力をおよぼし統合の中心となり， それがーつの super community として機能するととを仮説として明らかてした。そ してそれを metropolitan community とした (Mckenzie, R. D. The Metropolitan community 1933, The Rise of Metropolitan Community. Recent Social Trends in the United States 1935 p.443-496)。metropolitan community をとれ自体をし てとりあげ，その発展や性格を明らかにしょうとした点で，彼の業蹟はこの研究の基 礎をなすものとして高く評価される。

彼はこの場合，リージョンを生態学的意味における community として考えている。 （彼が社会学者である点からこれは当然だが，も一つは region が地理学で同質的な 地域を意味するから混同をさけてとくに metropolitan community としたことも考 えられる。尤も行論中には metropolitan region といら語をも使用しているが… こ

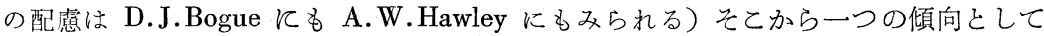
は人口の空間的，時間的分布をコミュニイティ構造の一側面としてみよらとする研究 が行われた。とれは彼が metropolitan community 形成の過程を解明するのに人口構 成，年令や性別の比，人種等を指標としているととにもみられ，後に E. E. Bergel が都市社会学の demography とするほどに発展して行った（Bergel，E.E.：Urban Sociology 1955 Part VI)。他の一つは制度, 諸機能の空間的・時間的分布に秝々てリ ージョンの性格と範囲を明らかにしよらうとするものである。Gist and Halbert ゃJ. A. Quinn の紹介するととろによれば，シカゴを中心に新聞購買圈をみた Park の研 究，新聞購買圏を指標に全米を41にわけた Mckenzie (Mckenzie，R.D. The Metropolitan Community, 1933. ch. 8)，シカゴを中心に家畜を指標とした Duddy and Revzan (The Supply Area of the Chicago Livestock Market, Chicago Univesity stndies in Business Administration (1931-32)), その他 W. J. Reilly, (Methods for the Study of Retail Relationship, University of Texas Bulletin Nov. 1929), M.L. Hartsough (The Development of the Twin Cities as a Metropolitan Market 
1924）などがあげられている。又地理学の方でも Dickinsonがこれをとりあげている。 (The Metropolitan Regions of the United States, Geogr. Rev. 24 (1934) p. 278 -291 ).

これら1930年前後の研究で重視されたのは中心都市がある機能に和々て支配的力を 周辺に及してらる事実及びその範囲を明らかにするととにあった。（尤も農村の側か ら出発しこれをみた Brunner や Kolb は都鄙共同体としての一体不可分性を強調し た（A Study of Rural Society 1935 ch. 7) が両者の統合を認める点では同じであ る。又 1934年 M. Aurousseau が都市は一つの社会集団の有機的部分と解すべきであ り，その発展が依存している地理的，経済的，社会的，文化的，政治的ニニットの部 分を棈成していることを銘記すべきである (Recent Contributions to Urban Geography. Geogr. Rev. 1934 p.445一55) といった発言や，1930年代に欧州で行われた regional center としての都市の研究一例えば Dickinson があげている自らの Leeds と Bradford 1930, W. Brosins の Frankfuurt-am-Main 1934, M. Schilling の Darmstadt 1935 (Dickinson, R. E. : City Region, Regionalism 1947), Durand の Aurillac 1939 (Tricart, J. : Cours de Geograhie Humaine. Fascicule II L'Habitat Urbain p.218), Lorenz の Plauens (Würzburg) 1934 (Schöller, P. : Aufgaben und Probleme der Stadtgeographie. Erdkunde. Band VII 1953 S.172) 等の研究 一がこの米国の人間生態学的研究とどのように関係があるかは明らかではないが無関 係であり得ないと思われる。）とれは機能的な統合体を見出すことでもある。その観 点から全米をリージョンにわけるとと或は個々のリージョンを明らかてするととは新 しい興味のある研究であり，後述するように実際的意味を有していたのである。し かしながらこのよらなリージョンがその内部に秃てどのような地域構造を有するか にはあまり関心がはらわれていないようである。

例えば Mckenzie はとの metropolitan regionalism の指標に metropolitan district と trade area をあげてらる。前者は中心都市への通勤圈に近く, ほぼガス, 水道, 電気等の公共施設が共通問題となり得る built-up area と一致する地域とした。後者 はこれを小売商圈 (retail shopping area) の意に用いているが，所謂 trade area と 混同され易々表現である（Mckenzie，R. D. : The Rise of the Metropolitan Community, op. cit. p.454)。けれどもとれらと彼が新聞を指標に設定したリージョンと 
の関係は必ずしも明らかではない。Park もシカゴのリージョンを新聞を指標にして 決定はするが，周辺 7 個の衛星都市における購買率の低下及びそれぞれのローカル紙 の卓越する範用を認めながら，乙れをりージョンの構造の問題まで発展さすととない 相互依存の程度の差として処理して終っている(Park E.E.：Newspaper Circulation and Metropolitan Region 1933 (Park, E. E. : Human Communities 1952 p. $210-218$ 。

ところで実際的な必要から進められた metropolitan region の研究も無視できない。 その一つは, 中心都市の商業的機能の営養空間を明らかにするととが, 商業経営の上 からる又競合する諸中心の政策的行政的立場からも必要とされた。

1927年卸売機能淿よる区分 (The Atlas of Wholesale Grocery Territories) が行 われたのが最初であるどされるが (Mckenzie op. cit. p.451)，個々の都市としても Minneapolis ゃ Chicago で検討された (Quinn, J.A. : Human Ecology p. 166)。 これらは商圏を指標とするものである。他の一つは都市計画の立場からなされたもの で,市域外に分散した人口,諸機能を含めて統一的な計画樹立のため生じた。 St. Louis やNew York の如きがその代表的なものであるとされる（Quinn. J. A. op. cit. p. 165-168。乙れら実際的な研究が前記の諸研究と相補ったことは容易に想像され るところであり，後述のセンサスにも関係してくるのである。ちなみに我国の奥井復 太郎（現代大都市論, 昭15) や石川栄耀（皇国都市の建設, 昭19）の先駆的研究は以上 の成果とつ栾がっている。

1950年前後におけりリージョンの研究は, 第二次大戦後の都市復興, 著しい郊处の 拡大を背景にしている。そして前に残されていたリージョン乃至ェリアの内部構造に 関する研究がとりあげられはじめた。即ら1950年 Quinn は Human Ecology の中で, 各機能のリージョン内に利ける location につ々て概括的な説明を試み, 同じ年 D. J. Bogue は人口及び卸売, 工業，小売，サービスの各機能を指標に metropolitan community の構造を解析し Mckenzie の提唱した dominance の仮説を検証した (Bogue, D.J. : op. cit. 1950。 又 Erickson は Urban Behavior (1954) 中の dominance の項で Bogue の研究を引用し各機能の構造てつ々てのの゚, Vance は Bogue の分析が必ずしも南部につレてはあてはまらぬとをから自らの方法（6つの指標を利 用)で南部諸州のメトロポリスのパターンを明らかてした。) Vance, R.B.and Smith. 
S. "Metropolitan Dominance and Integration" Vance, R. B. ed. The Urban South 1954 p. 114-134).

又 Dickinson は1947年 City Region Regionalism で各国に利ける city-region に ついて諸種の研究成果ををとめたし，我国では木内信蔵がメトロポール地域を整理し それぞれの地域を定め，我国におけるとの方面の研究に基礎をあたえた。（都市地理 学研究1951)

ところでリージョンは今世紀の新しい地域現象であり，新しい community の型で ある。それは交通通信機関の飛躍的な発展と流通機構の進歩によって变化して行くダ イナミックな属性をもつ。例えば近年航空機の進歩は大規模な空港を必要とするがそ れが中心都市内に夕られるのはごくまれである。中心的機能の分散はてとにもみられ， またとれによって中心都市の関係圈が将来かえられるととも考えられるととるである。 それ故1920年代の metropolitan region と現在のそれはかなり規模, 構造炕おいても 変化がある。そてでてれが米国ではセンサスにおいてどのよらにとらえられてきたか を朓めてぬよう。

センサスがこの現象をとりあげたのは1910年においてで，当時は漸く自動車が普及 発展しつつあった時期で metropolitan region（area）の発生期である。ここでは從 って都市と郊外 (cities and their suburbs) の語が用いられた。（そしてそれを二つ にわけ，イ・10万以上の市とその縁辺市境から10哩を cities and adjacent territory とし，口.人口 20 万以上の市とその周辺 10 哩以内で人口密度 150 人/哩の地域を metropolitan district としたのである。）との規準は 1920 年にもらけつがれたが，1930年 には一本となり人口 10 万以上の市とその周辺で人口 150 人/哩以上の地域を metropolitan district とした。この時は人口 5 万以上の市を中心に通勤圈, 電話, 水道, 下 水，新聞直接配橽圈等多くの指標により metropolitan district をつくろらとしたが その範囲がまちまちで，やむなく多くの指標による範团を含斥得るよう 150 人とらう 低ら人口密度を採用したといわれる。しかしととにェリアの普遍的な発達をらかがう ととができる。そして1940年には中心都市人口が5 万以上にかえられた。との変化ば 必ずしも理由のあるととではないといわれるが (Klove, R. C. “The Definition of Standard Metropolitan Area" Geogr. Rev. 1952 No.2) やはり metropolitanization の発展をみとめね渂るるい。 
さらに1950年には metropolitan district の質的な考察が実用化され，イ・人口密 度と非農業労働者人口を考虑すると共に，口. 社会的，経済的帘統合関係を重視した。 從来諸現象の綜合的表現として人口密度のみが用らられていたが，それがより科学的 な基準におきかえられたのである。そしててれまでの metropolitan district をやめ, 新しく urbanised area と standard metropolitan area の二つを設定した。前者は人 口 5 万以上の都市及びこれに接する suburb p urban fringe の密集した居住地及で 機能的に中心都市に関係のある目的で使われている territory を含むいわげ都市化さ れた地域であり，後者はメトロポリスを含む郡及びその隣接する郡で一定の非農業労 働人口を有し，中心都市と経済的，社会的に統合された郡を含む地域をさす（詳細は 省略 Municipal Yearbook, 及び土井喜久一：スタンダードメトロポリタンエリア地 学雑誌1953参照)。こらして metropolitan district ではもはや現実にはあてはまらな くなったのを認め，漠然としてらたその性格を二つにわけて明確にした。後者は明確 に機能的な関倸を指標にとりあげた点 metropolitan district とは異っている。そし. てその範囲はより大きいものとなった。

この区分と対象のとりあげかたにはまだ問題もあるが，とにかくこのよらなセンサ スの定義の变化は米国に和りェリアの発展に対応するものであり，乙の研究の指標: となった。

\section{2}

リージョン或はェリアについてをず問題となるのはその概念であろう。上述のいろ らろな呼称が具体的にらかなる性格の地域をさすかは必ずしも明瞭ではない。例えば Gist and Halbert は「リージョンは構造的, 空間的にはメトロポリスとその周辺集落 からなり，機能的には経済的，文化的，政治的諸関係の complex web であり，そと ではこれらの集落と大都市は主要中心とその從属部分といら一つのユニットで結合し ている」とのべ (Gist and Halbert, op. cit. p. 216) ている。とれに対し Dickinson. は各機能のグルーブはその範囲と性格を異にするしその地域は地理学的意味では必ず しも互に密接な関係があるとはいえないが都市に依存するといら共通の分母をもつ。 機能的に都市に依存してらるとの地域を cityregion とするとし (Dickinson R. E. : op. cit. p.165)，米国の場合につレてリージョンをあげているが，そてでは主とし て経済的機能を主とした中心都市の関係圏を取报っている (op. cit. ch. 6. 7)。J. 
A. Quinn はリージョンに大小二つの地域を認めている（Quinn, J.A. op. cit. p. 165)。我国でも同じ地域を或は大都市広域圈といい,或は大都市区域という場合もみら れる。(都市問題研究 6 の 2,6 の 4 )

これらの諸概念の不明瞭さは一つには既にみたよらにッージョン研究の発展にみら れる。もとを Mckenzie の metropolitan community 把握は機能的関係の人間生 態学的認識であり，具体的な地域との密着に乏しかったし大小の範囲が含るれていた。 又実際的研究でも商圏と都市計画といら異った立場から発展してきた。これらが不明 瞭さを導らた一因と考えられる。しかもリージョンそのものがダイナミックな属性を 有する点が事情を更に複雑にしたよらである。即ち都市を中心とする機能的な関係圈 は指標によって必ずしも同じ範囲を示さない。のみならず機能的結合の実態も同様で はない。そしてそれらは交通，通信の技術的進歩を媒介として変化する。又とれらを 地理的な地域として地表に定着させるとと自体困難を伴らととであるからである。そ こで今少し諸家の説をあげてみよう。

これと関して比較的明確にその考をのべているのは J. A. Quinn である。彼はェ リアを metropolitan district, industrial area, metropolitan regionの三つにわけた。 前二者は決定の基準が異るが（前者は主に人口を指標とし，後者は工業を指標とする） が共に行政区域外飞拡大された都市的地域を中心市と一体のものとしてみる greater city をさす。即ち都市的であるという意味で同質的孪地域である。これ亿対しリージ ョンは機能的に中心都市と結合関係にある一つのまとまった地域であり農村をも含ん だ多様な異質的地域の統合体，換言すれば結節地域であるとする（Quinn，J，A．： op. cit. p. 163-165……筆者の判断)。としてリージョンは圈構造的とは central city, adjacent suburbs and satellites, outlying rural communities をなず前二 者が metropolitan district をなすとする。(ただしこれは1950年以前に考光たもの) Thomas and Queen も最後の点で同じ見解である (Thomas S. A. and Queen, L. F. : The city 1939)。A. W. Hawley は community area の語を使用するがメトロポリス もかぎられた primary area をすつとしてデトロイトの場合を例ととり通勤圈及び retail shopping areaをこれにあて（集合生活の daily rhythum を重視）ささらに第 二次，第三次の communal area を設けている (Hawley, A. W. : Human Ecology. 1950p. 255-258)。彼はをた Bogue の著書への序文で metropolitan community を「ex- 
tensive community であり諸機能の地域的飞専門化した多くの部分からなり，中心都 市の働きにより関連しあら統合されている」ものとしているがそれを daily movemrent に関係さしている点よりみると前揭の意味に近らものと考えられる。(Bogue.D. J. : op. cit. p.5)

W. C. Hallenbeck は「日常生活のプロセスにおいて諸活動や人々が相互に関連し あったコンプレクスとして不可分におりなされているょら六中心市と, その周辺の地 域」を metropolitan community とし, (Hallenbeck, W. C. : American Urban Community. 1951. p.224-258) Gist and Halbert も前記のようにとれとよくにた 考をのべている。しかし彼の場合その行論中には広ら意味のリージョンにもふれてい る。Bergelは中心都市により統合され支配されている多様な都鄙集落の複合した組織 としてリージョンをタる。しかしそれがきわめて urban な性格のものである点をとく。 (Bergel, E. E. : Urban Sociology. 1955. p. 141) Bogue はリージョンを広い範 囲にとり， zone of direct participation (25哩末で), zone of interchange (25-64 哩) zone of exchange (65埋以上) てわけている (Bogue, D.J. : op. cit. p. 54)。 metropolitan region の語は米国以外ではあまり用らられないが，同様索現象は注 目されている。R.E. Dickinson，は前記のよらにcity-region としててれを考元，都 市の周辺を urban tract, city settlement area, city trade area そわけている。 (urban tract は conurbation に先だって密集して連結した urban built-up areaを 決定するに用い, city settlement areạ はこれに rural-urban fringe を含め, trade area は更にひろい範团をさしている。) (Dickinson. R. E. : City Region, Regionalism 1952 p. 168-171) 又 Schrefter は Frankfurt そつ々て大小二つの地帯を区 別してらる (Dickinson, R.E. : op. cit. p. 190-191)。G..Chabot \& la banlieue immédiate, la moyenné banlien, la grande banlien と都市の影響带をわけ, metropolitan region を les régions urbaines と称している(Chabot, G. : Les Villes 1950,p.185-192)。我国では木内信蔵がメトロポール地域を三つにわけて説明してい るのは周知の通りである。（木内信蔵：前掲書）

以上のような諸説は Mckenzie のふえんにすを゙ぬものか Bogueのように帰納的 であるものまで多様であり，又との観点も機能的関係を主とするとはい方多少差異が ある。りまとれらの個々について議論する余裕はないが, 共通点としてリージョンが 
空間的にある程度区分されれていることが認められる。しかしとの区分の基準が何で あるかは必ずしも明瞭ではない。

リージョンの研究がよりみのり多い成果を得るためとはこれらの用語のもつ概念が 主要孛ものについてだけでも統一され共通の理解の上にたつととが是非のぞまれるの である。

木内信蔵はメトロポール地域を前述のように三つにわけたがそれぞれに固有の名称 をつけなかった。そのため我々がそれを借用する場合でも第一の意味のメトロポール 地域，第二の意味のメトロポール地域などと限定しなければならず不便である。 その他では磯村英一が社会学上よりの三つの性格を広域圈についてあげているが勿論 名称はない，そしてこれは地理学の立場とは遠い。

私見によれば，機能的統合体としてのリージョンはその統合の媒体となる機能の質 的性格によって大体を区別すべきではないかと考える。その場合，中心との機能的関 係が主に直接的であるか主に間接的であるか，物によってつながるか，人によってつな がるかが指標となるであろら。これらからして第1に都市及びその周辺のほとんど都 市化されている地域即ち中心市としての機能を行っているところで Chabot，Dickinson，木内信蔵の第 1 圈にあたる地域を一つ考臭る。ここで都市化というのは景観的 にも殆んぞ中心市に連担して拈り，機能的には中心市域と同じ性格をもつ意味で，い わばこの地域は sub metropolis である。中沢誠一郎の大阪市域の決定もこれにあた る（中沢誠一郎：市域決定の基本的調査方法について都市問題45の 5)これをメト口 ポリタンコア(核心都市域)とよぶ。第 2 はその外側(必ずしも同心円的ではない)，日 常生活が直接的に人の動きによって中心と結びついている地域，中心市を中心とする 共通の組織体系の下に日常生活が営まれている地域である。これは通勤圈を主な指標 として考它られる。これをメトロポリタン・エリアとよぶ。第 3 はさらに外方，直接 的に物の動きによって中心と結びついている地域（大都市地域）をいら。これをメト ロポリタン・リージョンとする，第 4 は主として間接的なつながりにおいて中心市と 関係している地域（大都市広域圈）で，これを大都市関係圈（勢力圈）とよぶ。

第 2 と第 3 は木内信蔵 Bogue，の第 2 圏にあたる，第 2 メトロポリタン・エリアは Dickinson, Queen の第 2 圈, Hawleyの primary community area にあたる, 第 3 リ ージョンは直接供給圈, 直接配達でトラックの輸送圈に近い，人の動きよりみれば信: 
週単位の接触圏にあたる。本来 2 と 3 は同じ範囲位においてみられたが近年の交通通 の発展は両者を分離しつつあると思われる。第 4 はきわめて多様な内容をるつから各 指標間の相異が多くなる。以上は一つの試みであるがさらに研究を進めたいと考える。

\section{3}

つぎにリージョン研究上問題となる二三についてみよう。とれを地域構造上からに 限ってみると一言にしていえるととは，その内部構造が前述のような諸研究てもかか わらず，都市の構造分析にみられる程には明らかにされていないというととであうう。 これには従来の研究方法にも由来すると思う。即ちこれまでのリージョンの研究は性 格論が主であった。そして少し行われた地域構造の解明には少なくともつの前提が あった。一つは中心からの支配的力のみに注意し, しかもそれが圏状に傾度（gradient）をもって推移すると考えたととである。他の一つはその中心が漠然と単一であ ると予想してらたととである。

リージョンの成立を特色づけるものが中心市のドミナンスであるととは認めるとし てもその一方的な動きだけで地域の構造をみるうとするのは不充分であろら。何故な らばそれは前記のように多様な異質的な地区一例えば Bergel のレら如く rural sections, rurbanized areas, conurbations, villages, towns, cities, agglomeration of cities 等 (Bergel, E.E. : op. cit. p.141)一からなる一つのまとまりであるから中 心のドミナンスに対する関係はまちまちであり，かつとれら異質的流ものの相互関係， それらが中心に対してもつつながりこそ問題とされねない。例え椲星都市が リージョンの中でどのように位置づけられるか，機能的に專門化した地域がどのよう な相互関係をもち中心とつながるかなどは，傾度の圏状分析では尽し得ない。重点は 多様を都鄙集落の複合統一体そのものの解析におかるべきであって，その時前述の前 提は一つの方法にすを゙なものとなる。この点から sector theory, multiple theory， 或は累層分析の方法等が考慮されねばならないであろら。この意味でバージェスの圏 構造が大都市の分析には不適であるとする磯村英一の所説（大都市広域圈の社会学的 考察, 都市問題研究 6 の 4 ) は同様にリージョンにもあてはまると考える。そしてて れらからリージョンまたはェリアの定型分析の理論型がつくられねばをるまい。

日本の都市につらてその発達過程から市域構造を明らかにした藤岡謙二郎（先史地 域及び都市域の研究 1955)，首都圈における中都市千葉の性格につ々て諭じた清水輻 
八郎, 山鹿誠次（日本都市学会千葉綜合調査委員会 : 大都市圈における中都市の機能 1956), 中京大都圏の研究を進めた高野史男（東北地理1956），社会学の立場から立体 的構造を重視する磯村英一（溋掲都市問題研究 6 の 4 ）等の諸研究はこの問題に対し 多くの示晙をあたえるものである。

つぎに中心核の問題につレてみると，Dickinson もんらようと米国のリージョンや エリアはその国土の広大さの故に大西洋岸を除けばかなり明らかにその領域が画定さ れ，中心も一つの場合が少をくない。しかし我国や英国では国土が狭く中心都市の近 接，連合によってリージョンやェリアがつくられるととが多い。とれは例外というよ りむしろリージョンの1つのタイプと考えられる。中心都市がその勢力圈を大洋をと えて世界的に拡大さす現代に和いては特に海岸に臨むものが多くそれはとのような傾 向をもちやすいからである。この場合中心都市が行政的にはわかれてらても 1 つの実 質的学凝集体であるものや，コンナーベーションをしているがそれぞれ核的性格を失 っていないるのなどがある。従ってこれらの相異による構造の研究も一つの課題であ ると思う。

以上は機能的関係を主としてェリアの構造を問題としたが，一方において人間の行 動に主眼をおいてみなければをるまい。中沢誠一郎は市民の日常生活圏が，古典的生 活圈の解消後にあらわれた 2 つの生活圈の 1 つである（他の 1 つは大都市の生活関係 圏）とのべているが（大都市区域の生活圈的考察, 都市問題研究 6 の，1954）リ一 ジョンの構造はこの立場からも考元る必要がある。またやや立場は異るが磯村英一が 「都市の構造」及び「機能と生活の構造と意識」の二つの面から研究するととによっ て都市社会の綜合的観察が成立するとする点（都市の地域社会と生活構造, 都市問題 48の $8 ， 1957)$ にものととはみられる。我々の立場からは意識まで進む必要はない が人間の行動空間, 日常生活圏をェリアの基礎的要素としてとりあげるととも大切で あろら。との点では Riemer の contact pattern が参考となる。(Riemer. S. : The Modern city 1952 p. 173)

最後にリージョンやェリアは前述のよらに同質的地域ではなく結節地域である。そ れ故広く地域論（高野史男, 地域棈造としての都市圈網地評 30 の 9,1957 ) とか都市の 階層的配置の問題（石水照雄：都市の階層的配置, 都市問題48の 9,1957) につながっ てくる。リージョンやェリアの発展は少なくとも二つの問題をもつと思われる。前述 
のよらスリージョンは大別して3〜4の区分をなし得るが, urbanized area は Bogue のいらょうに suburbではなく submetropolis である。つまり都市域の拡大を意味 する。そしてさらに周辺ではてれるで比較的局地的にまとまっていた基本的生活圈を 分裂させ，その一部を中心都市に結合させるととによってかなり広空間に都心を核 とする輻輳的学関係を成立させる。そしてそれは都市的という意味で同様な性格のひ ろがりを拡大させるととにもなる。一方外方の地域は階層的索構成をしている。それ 故てのよらな地域ではクリスターラーのいうような都市配置関係はいれられにくい。 中心都市的性格の地域は点ではなく面的なひろがりであると対し，リージョン周辺の 都市は点的であるからその接触部の構造がきわめて重要な意味をもってくる。んわば エリア的構造と階層的棈造の接触, その变質を内包する。それ故リージョンやェリア の地域は独自の考察を必要とするに至るのではあるまいか。

つぎにリージョンとリージョンの関係がある。Dickinson の作成した1934年のリ一 ジョンでは第一級のメトロポリスが 21 げられている。しかしそれらが今日必ずしも 同位にあるわけではない。Vance と Smith の南部に利ける研究によれば超メトロポ リスと国内的メトロポリス，第二級のメトロポリスに階層づけられている。（Vance and Smith : Metropolitan Dominance and Integration. The Urban South, 1954) これは指標とする機能の相異にもよるが，それらの機能そのものが階層性を有すると とも考虑される。リージョンのとらした分化に伴う層位関係を明らかにすることは結 節地域の地域論的研究や都市の階層的配置の問題へつながるであろう。

リージョンやェリアの研究は前述のように人間生態学の分野からはじめられた。し かし最近社会学の傾向は地域構造よりも生活構造・意識構造に重点がさけられつつあ ると々われる（磯村英一，都市研究に打ける社会生態学理諭の展開，人文地理 8 の 6 , 1957)。そうなればなるほど我々の側からする分析が必要となるのではあるまらか。

(立命館大学文学部講師)

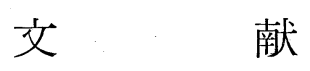

解 題

A. I. Preobradzenskij : Okönomische Kartographie, Veb Hermann Haack, 